Ssciendo

DOI: 10.2478/RAE-2019-0036 Review of Artistic Education no. 182019 324-329

\title{
6. ARTISTIC EDUCATION/ EDUCATION THROUGH ART IN CONTEMPORARY SCHOOL FROM A TRANSDISCIPLINARY PERSPECTIVE
}

Marina Cosumov ${ }^{313}$

\begin{abstract}
Man is the only being that lives in the world not only biologically, but also spiritually, essentially due to education, which is permanent, continuous, omnipresent and creates values. Lifelong education represents an organizational and philosophic principle which requires that lifelong education throughout a person's existence determines each individual to develop his/her personality with the help of a complex system of means, which must meet his/her educational and cultural needs and ambitions. Art is the fundamental dimension of education that uses in the development of personality the educational potential of the aesthetic, social and natural beauty.
\end{abstract}

Key words: lifelong education, education through art, aesthetic-artistic values, personality

\section{Introduction}

Lifelong education represents an important direction for the evolution of the activity of building-developing personality, which aims at the capitalization of all the dimensions of education designed and achieved throughout human existence and at any moment in time of the human existence. The methodology of permanent education highlights the action resources of the activity of building-developing personality valid on the vertical and horizontal of the system.

This approach allows the integrity of all lifelong education resources on the vertical of the system (continuity between education stages, supported throughout human existence) and on the horizontal of the system (complementarity of education resources, studies thoroughly at each level of the education stage, at any moment throughout the human existence) (Figure 1):

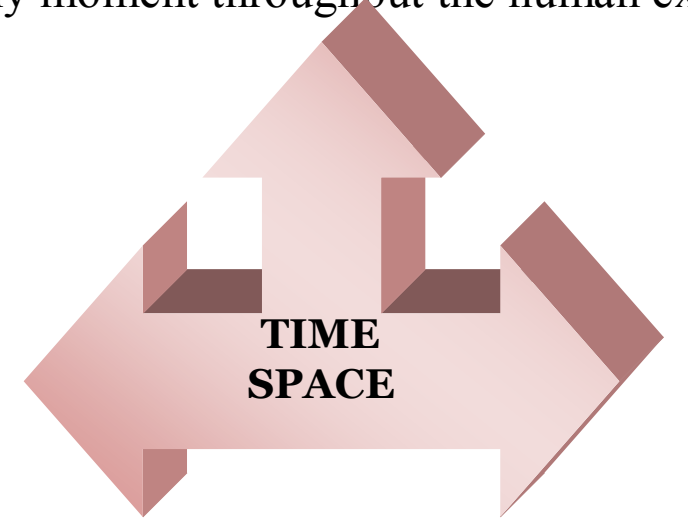

Figure 1. Determinate coordinates of lifelong education

\footnotetext{
313 Associate Professor PhD., „Alecu Russo” State University from Bălţi, Republic of Moldavia, email: cosumov@mail.ru
} 
On the vertical of the system, permanent education ensures the temporal openness of the activity of building-developing personality, fully carried out throughout the period of human existence. The balanced (re-)distribution of the contents (intellectual-moral-technological-aesthetic-physical) and of the forms (formal-non-formal-informal) of education ensures the successive capitalization of the resources of each age (school/post-school) and psychological resources, but also the extension of the positive attitude towards training and self-training, necessary for the purpose of executing the natural and social roles and statuses performed by the human personality throughout its existence.

\section{Discussions}

The definition of lifelong education, at the level of a fundamental concept, entails the delimitation of the reference field and of its strategic significance (Dave, R. H.).

As a reference field, lifelong education consists of the "entire lifetime of an individual". It aims at the activity of building-developing human personality, approached "in its entirety", correlating the resources, namely:

- stages of education (ages: pre-school-school-post-school) and psychological stages; (life cycles: childhood-pre-adolescence-adolescence-youth-maturity-old age);

- contents of education (dimensions/aspects of educations: intellectual-moraltechnological-aesthetic-physical);

- forms of education (formal-non-formal-informal education);

- factors of education (role: of family, educational communities, education establishments, etc.).

As a strategic significance, permanent education can be defined at the functional-structural-operational level, level that emphasizes:

- the final goal ("to maintain and to improve the quality of life");

- universal and dynamic nature ("represents the democratization of education and allows the adjustment of materials and means of learning to the new development conditions imposed");

- managerial significance ("lifelong education is an organizational principle for all types of education").

At the functional level, permanent education employs three categories of functions: adjustment function; innovation function; rectification function.

At the structural level, lifelong education employs two main components, in interaction relations: the general component and the professional component.

At the operational level, lifelong education employs pedagogic/trainability development resources of each human personality, capitalized in terms of individual and social opportunity and motivation.

Thus, lifelong education simultaneously represents:

- a fundamental integrator pedagogic concept which incorporates all the resources for the activity of building-developing human personality (stages, 
contents, forms, factors), capitalized on the vertical and horizontal of the education system;

- an operational pedagogic concept which extends its applications "on all aspects of education" (Thomas, J.);

- a pedagogic principle which supports the global organization of a complete educational system, open to all types of education;

- a direction at the level of education politics, which aims at perfecting the activity of building-developing human personality throughout lifetime through the complete capitalization of its self-training and self-education resources.

The principles of lifelong education, "underlie the global organization of the education system" which employs all life cycles, from the preparation stage which promotes the assimilation of school and extra-school values - to the active stage - which entails professionalisation on a social mobility basis - up to the retreat stage - which allows the personality to take new roles by continuing the education.

Permanent education, in the conditions of contemporary society, becomes "a theme of meditation and of action" which employs "theoretical thoughts" but also "practical suggestions", operable at various levels of social representation: education for all, parents' education, education for democracy, education for professional improvement and re-qualification, etc., which stimulates even the designing of "a didactics for adults" (Urban-Czyck, F.).

These coordinates confirm the stability of a direction for the evolution of education: "the persistence of permanent education." Such a direction does not exclude, but, on the contrary, employs the flexibility of lifelong education, for which aesthetic education represents a requisite component.

Art, states D. Salade, "meets certain real needs that any person feels for the purpose of enlightening certain ideas, of accounting for certain behaviours, for underlying certain attitudes, suggesting, explaining, capitalizing or systematizing problems. Through its demanding, invigorating, optimistic, etc. nature, art pushes towards the love of truth, good, science and life." Due to the force of influence, art has been used for ages as an educational means. Since the age of Homer, from Ancient Greeks, going through the Renaissance concerned with the execution of a multilateral development, getting to the Neo-Humanism of the $18^{\text {th }}$ century, which emphasizes the role of art on the process of education, and up to the Modern age, people have always been preoccupied, in various manners, with the performance of aesthetic education. The mutations occurred in the contemporary world, progresses in the field of science, technology and art, increased urbanization and industrialization, computerization have undoubtedly also influenced the aesthetic, which has infiltrated all areas of life and human activity. Nowadays, the idea according to which human existence in all its determinations, including of artistic education/through lifelong art, should be ruled in terms of the laws of beauty, of harmony, in a nutshell, according to the laws of the aesthetic, is unanimously accepted. 
The two levels on which aesthetic education is situated are: reception and artistic creation. In the process of reception several aspects are pursued: sensoryperceptive training through direct contact with works of art and cognitive training, which entails, on the one hand, a set of information on the work and its creator, as well as the need for integrating these in more ample contexts, and, on the other hand, it aims at developing intellectual abilities for the purpose of working with codes specific for various art languages.

Aesthetic education has an infinity of positive effects on personality. The most significant amongst these aim at the quality of children's socialization process, maturity of the social-moral status (courage, inter-human communication ability, and so on), intellect development and refining as a rational and evaluative-critical structure at the mental level, pleasant and efficient organization of free time through the recreation of a personal universe in the sphere of the imaginary, of emotions, of motivation, of motor skills and of will, asserting and experiencing the feeling of cultural identity close connected with the stimulation of the capacity to love the nation's artistic heritage, stimulating initiatives in the practice of arts, etc.

\section{Results}

As a synthetic statement, aesthetic education is what re-teaches the child "to life inner harmony and the balance between the forces of imagination and those of action, between dream and reality, between the ambitions of the I and acceptance of reality, between the duties towards oneself and towards peers. Living in beauty entails and interest for measure and harmony, thus, a superior morality; a superior moral training leads to joy - an effect and sign of inner harmony and balance - and on the level of action to fecund dynamism." By stimulating expression and originality, aesthetic education is in the sphere of a pedagogy of creativity. It imposes the development of the ambition of a welldone and beautifully done job, and the tastefulness for any industrial products, the sense of balance and the simplicity of beautiful, civilised behaviour. Aesthetic education, in the context of lifelong artistic education/education through arts has in its essence the development of personality by means of the beauty in art, society and nature.

Artistic pedagogy aims at two aspects in the process of developing the future personality: education for art, which means the education of the artistic sensitivity of the child interested in discovering, knowing, creating and being trained through the values of art and education through art, with much more ample educational valences, which aims at the complete development of personality.

Artistic education becomes a complex initiation and development process for the purpose of the creative understanding of arts and of the influence of art on the development of human consciousness. Artistic education in educational establishments entails, first and foremost, an aesthetic sensitization of learned 
persons and leading them towards the understanding, appreciation and creative assimilation of arts through a continuous and systematic process. This process also determines a capitalization of the training potential of the material and spiritual values of society. The possibility of influencing the spirit through art is ensured by the fact that aesthetic emotion constitutes a complete employment of personality as a response to the system of values existing in the work perceived, the finality of artistic education becoming a training of the skills (abilities) of receiving, integrating and creating authentic expressive structures.

We cannot imagine the contribution of education through art and its influence in the training/development of human personality, without capitalizing the Good, the Truth and the Sacred morally, spiritually, in terms of behaviour and socially.

As a synthetic statement, aesthetic education is what re-teaches the child "to life inner harmony and the balance between the forces of imagination and those of action, between dream and reality, between the ambitions of the I and acceptance of reality, between the duties towards oneself and towards peers. Living in beauty entails and interest for measure and harmony, thus, a superior morality; a superior moral training leads to joy - an effect and sign of inner harmony and balance - and on the level of action to fecund dynamism.", C. Cucoş specifies in his researches [2, p. 75].

Aesthetic education represents "the activity of building-developing human personality through the beauty in art, society, nature, received, assessed and cultivated at the level of human sensitivity, of reason and creativity." It was and is a permanent component of education, of a person's training for life. Beauty, with an ample meaning of aesthetic, has always been considered one of the essential values, that must be cultivated in people's consciousness, together with truth and goodness.

The term aesthetic is of Greek origin (aistetikos) and refers to sensitivity, to sensory perception. Later on, the meaning of this term was that of what impresses, what excites a person. As man is especially impressed of what is beautiful, the notion of aesthetic was understood for a long time as a synonym for the notion of beautiful, and aesthetic education was defined by beauty and through beauty.

Aesthetic education is not synonymous with artistic education, for the aesthetic aspects of reality are found not only in art, but also in nature and in social life. Nature presents many aspects that impress a person: colours, landscapes, auditory phenomena.

But the most complex and deep aesthetic impressions are generated by art (literature, music, painting, choreography), thus artistic education represents the essential part of aesthetic education. From a pedagogic point of view, the distinction between the two is expressed not only in terms of content, but also of finalities and means of execution. Aesthetic education has a more ample sphere, 
it refers to all three categories of aesthetic values - of nature, of society and of art - thus, its methodical sphere is more various.

\section{Conclusions}

Artistic education/education through art operates only with the values of art, entails the development and cultivation of creative abilities in the methodical sphere, specific to each type of art, and the force of infiltration into the human personality is more deep. Artistic education, an essential factor of aesthetic education, is carried out by knowing beauty, through the mediation of various arts: literature, music, dance, painting, theatre.

The conditions of modern life are the ones that each human being learns, must learn every day. The school is the place where this learning begins, and the skills that the child receives here must offer him/her the necessary items so that in the future he/she can work by himself/herself on his/her improvement: education through art constitutes an initiation, an openness..." $[5,107]$.

Aesthetic values constitute an essential feature in education through art. Therefore, aesthetic education has an important role in the development of personality and this process depends on what is offered to the child, especially in the sensitive periods of development, subsequently, aiming at a continuous evolution whose finality is assessed in terms of psycho-emotional and intellectual maturity.

Education through art, carried out throughout one's lifetime, is that dimension of training that aims at the training of the person for the purpose of intercepting, interpreting, internalising and creating values, effected in various supports or situations (art, nature, human conduct, community, etc.), for the purpose of improving spiritual fulfilment and of imprinting a superior meaning to the human existence.

\section{References}

1. Cristea, S., (2000), Dicţionar de pedagogie, Ed. Litera, Bucureşti;

2. Cucoş, C., (2014), Educaţia estetică, Ed. Polirom, Iaşi;

3. Gagim I. (2003), Dimensiunea psihologică a muzicii. Ed. Timpul, Iaşi;

4. Guţu V. (2005), Managementul schimbării în cadrul educaţional. Ed. ARC, Chişinău;

5. Dave R. (1991), Fundamentele educaţiei permanente. Ed. Humanitas, Bucureşti;

6. Roco M. (2001), Creativitate şi inteligenţă emoţională. Ed. Humanitas Bucureşti. 